\title{
DISCOVERING LEARNING POTENTIALS IN THE WORK PROCESS: AN ANALYSIS OF WORK STRUCTURES AND WORK TASKS USING THE EXAMPLE OF PRISON OFFICERS
}

\author{
Görl-Rottstädt D* \\ University of Applied Sciences Dresden (FHD), Germany
}

\begin{abstract}
Prisons are in a state of constant institutional change, marked by extensive development processes. The subject of different studies is the analysis of development processes in prisons, for which suitable strategies of organizational and personnel development are required. In this context, the area of further vocational training is of particular importance, whereby this should be based primarily on the training of the prison officers. The research question that arises is how to combine work and learning in a meaningful way. The contribution will focus on the results of own empirically determined possibilities for the use of work structures e.g. rotation and conference system which are both conducive to learning but also conflict-prone. The further systematization of the work tasks of prison officers has the purpose of presenting their varied and demanding professional profile. So far, too little attention has been paid to this aspect, although this area has considerable potential for the successful implementation of development processes. In this context, work-related learning means a conceptual development geared to all hierarchical groups of prison staff, which is oriented towards current work problems and conflicts solution. The complex methodology includes 42 expert interviews, 51 workplace observations and 8 group discussions in three Saxon prisons in Germany, which were evaluated with the qualitative content analysis. The results of the study will show how learning processes can be designed according to pedagogical insights to make learning content of work structures and work tasks in prisons more consciously. In conclusion it is essential to establish that only networked work and further training structures to develop the prisons into a learning organization in the long term and at a high level.
\end{abstract}

Keywords: Prison staff, learning counselling, learning support, Competence development, learning organization

\section{Introduction}

An office where people write on the computer or a factory where it smells of machine oil - such jobs are normal. But there are also other jobs. The author would like to introduce to a workplace that deviates from the norm and would like to explore the learning potential in the work processes of prison staff.

In the implementation of personnel and organizational development in the prison system, further training is playing an increasingly important role as a strategic and connecting element (cf. Wiesner et al., 2003). It is unquestionable that managers in prisons are challenged to integrate the prison officers as the central occupational group, more closely into personnel and organizational development, but 
that considerations must also be made as to which learning location combinations are suitable for organizational and personnel development in order to successfully manage development processes (cf. Görl-Rottstädt, 2011; Görl-Rottstädt, 2019; Görl-Rottstädt, 2020a).

The motivation for continuous, work-related learning, which is dependent on the design of work tasks and work structures that are conducive to learning (cf. Erpenbeck et al., 2003, p. 147), is ideally made possible by the development of a learning content of these structures by managers. The learning opportunities created by the managers, support and accompany the employees in their respective work processes. The research question that arises is how to combine work and learning in a meaningful way. Building on this, the article also deals with the question of how the interrelated components of working and learning can be better coordinated in the work tasks and how they can be designed in a competence-oriented manner.

Against this background, Aulerich demands that managers support personnel development through competence-oriented learning (cf. Aulerich et al., 2004, p. 136). In her studies, Bergmann (2001) emphasises that "the scope for developing vocational action competence is shaped by the work situation" and that "vocational action competence is a characteristic that must be constantly developed in the work process and that depends largely on the work situation." (Bergmann, 2003, p. 6) Intentional vocational competence development occurs primarily in the active examination of workrelated content in the context of initial and continuing vocational training. This leads to the consideration of showing how self-determined learning of the selected target group is initiated and organised. Both, the academic discourse and the practice of continuing vocational education and training deal with the meaningful relationship between work and learning as an interdependent relationship (cf. Görl-Rottstädt, 2011, p. 5).

Consequently, learning processes must be designed in a work-related and cross-cutting way according to vocational and adult educational findings, in order to simultaneously use the learning content of work structures and tasks more consciously (cf. Bergmann 2001). The development of competences that can be achieved in this way is understood, following the research and development programme "Learning Culture Competence Development", as a "process in which the technical, methodological and social ability to act as well as the ability to organise oneself [...] is expanded, restructured and updated." (Sauer, 2000, p. 7) With regard to the design of change processes and the development of the necessary competencies, it has been shown that "...with forms of learning that are directly integrated into the process of work, the effectiveness is demonstrably higher than with traditional forms of further training." (ibid.)

\section{Background of the subject and the authors' contribution}

Prisons are described in the literature as an example of a total institution (cf. Goffman, 1973, S. 11). What does this mean: The prisoners' work and life processes are subject to clear regulations, norms and values. Just as the daily routine of the prisoners is strictly regulated, so is the daily routine of the staff too. The working relationships between staff and prisoners are much closed together. And this has clear implications for aspects of the author's research. In the literature the situation of the staff is often excluded. But in the authors work, she has dealt exclusively with one side of the interaction relationship - with the prison staff. Görl-Rottstädt (2011, 2019, 2020a) was interested in the design of their work and learning processes with the focus on learning counselling and learning support. 
The author had already won a first impression of the situation of the working and learning processes by working on different projects in the Saxon prison system in former project. The results of the project also show problems with the quality development of the internal staff training in prison. This is due to the fact that the coverage of further training needs was to be increasingly transferred from external to internal training structures. However, prisons are not enough prepared for these new requirements (cf. Wiesner et al., 2003, p. 76-81).

The targeted selection of the Saxon prisons in the own empirical research is based on the complexity of the structural and procedural conditions of the respective organization, which serves as a basis for discussion on the transferability of aspects of the study. With the consideration of obtaining targeted, comprehensive and differentiated results, the following three correctional prisons and a Saxon further training centre were selected as a justice-related further education institution:

Prison 1 is characterised by a very complex differentiation in terms of the forms of detention and housing and the prison structure (e.g. male and female prison, regular prison, residential group prison). These enforcement structures place extensive demands on prison officers. This background is linked to the expectation that a broad, representative spectrum of occurring work problems will be covered by the enforcement differentiations. Furthermore, since its foundation in 2000, the prison has, through the implementation of the team development concept, pointed to a relatively stable status in the personnel and organizational situation, which allows individual development stages over a longer period of time for the investigations of the present study. Although the employees of the prison are familiar with their work processes, the in-depth examination of work problems that arise is carried out with particular attention to the full differentiations that form the starting point for possible optimisation of further training structures.

Prison 2 is viewed against the background of extensive restructuring processes, which are characterised by the completion of the team development concept and the introduction of first offender execution. In the same way, the existing high proportion of older employees working in the GDR penal system means that a differentiated consideration of change processes and task profiles in historical and political change is required.

Prison 3 represents a complex field of investigation as a combination of structural and procedural differentiation of the organization. With a structure similar to that of prison 1, there is a multi-layered differentiation. Furthermore, prison 3, like prison 2, is undergoing a comprehensive change process due to the introduction of the team development concept. Prison 3 originally served as a review of the results obtained in Prisons 1 and 2, but in the course of the investigations it became apparent that Prisons 1 and 2 are more advanced in the development process, so that an adequate comparison is hardly possible. For this reason, the results obtained in prison 3 are included in a generalised form in the presentation of results.

The external training is carried out by further education institutions close to the justice system. The Saxon Prison School, for example, began its work in 1992 after the change in Germany. The training centre is an important part of the analysis to show the systematic integration of further training in change processes by aligning the training structures to the training needs and the professionalisation of the further training personnel. 
The author will concentrate on presenting the results of the investigation of these three selected prisons in Saxony. Of the personnel, as it is set up here in the hierarchical structure, she was particularly interested in the group of employees of the General Enforcement Service, called prison officers, in relation to the departmental management, departmental service management and the specialist and social services which is shown in figure 1 (cf. Wiesner et al, 2003; Görl-Rottstädt, 2019, p. 14). The departments form the ideal starting point for examining and documenting the design of development processes as well as the analysis of work structures and work tasks in prisons.

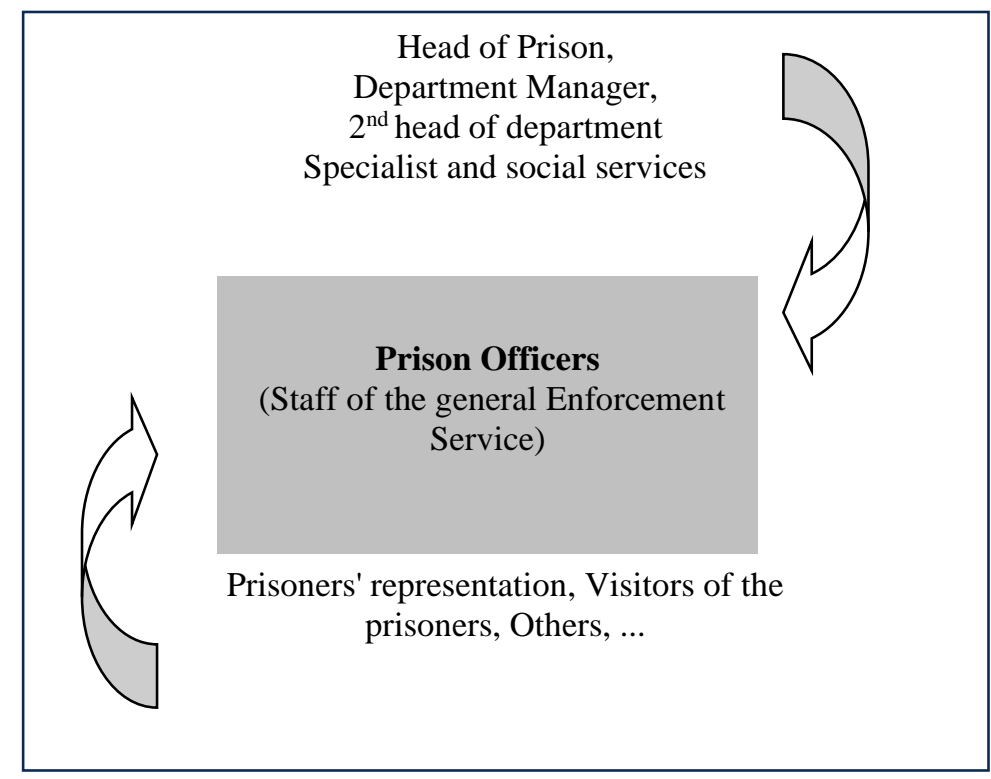

Figure 1: The prison staff in the hierarchical structure of the departments (own representation according to Rottstädt, 2006, Wiesner et al., 2003)

The aim of own empirical research is to describe the professional competence of prison officers and the learning potential of their work tasks. According to Burgheim/Ostheimer (1994) in order to cope with changes in the current prison system, the professional self-image and thus also the task profile of staff working in the prison system are developing further. This applies in particular to the prison officers. The prison officers are primarily responsible for security tasks. A new field of activity relates to the performance of "treatment tasks". These include elements of counselling, accompanying and caring for prisoners, with the aim of supporting their rehabilitation.

Although initial scientific studies on the job profiles of prison officers exist, there has been a long lack of concrete, empirical surveys on the task and competence profiles of this occupational group. The present research work helps to close this scientific gap. With the systematic development of task and competence profiles of prison officers, the author assesses the learning potential of work tasks. In the same way, managers and those responsible for education in the prisons receive qualitative support in fulfilling their responsibility for continuing education.

\section{Methods used}

Table 1 shows how the individual phases of the investigations are linked and coordinated. The table shows the course of the investigations as a connection of investigation targets, sub-steps and methods of collection and evaluation. 
Table 1: Relationship between study targets, sub-steps and methods

\begin{tabular}{|l|l|l|l|}
\hline $\begin{array}{l}\text { Target reference - } \\
\text { research problem }\end{array}$ & Sub-steps & Survey methods \\
\hline $\begin{array}{l}\text { Target - } \\
\text { Description of } \\
\text { professional competence } \\
\text { of staff and the learning } \\
\text { potential of their work } \\
\text { structures and tasks }\end{array}$ & $\begin{array}{l}\text { Analysis of the work } \\
\text { structures and tasks of the } \\
\text { staff } \\
\text { Identification of } \\
\text { competences and work } \\
\text { problems } \\
\text { Analysis of the learning } \\
\text { content and learning } \\
\text { facilitation of work } \\
\text { structures and work tasks }\end{array}$ & $\begin{array}{l}\text { literature and document } \\
\text { analysis } \\
\text { oral interviews } \\
\text { workplace observations } \\
\text { individual expert } \\
\text { interviews or group } \\
\text { discussions }\end{array}$ & $\begin{array}{l}\text { Development of a } \\
\text { practical and theoretical } \\
\text { reference framework } \\
\text { Reconstruction analysis }\end{array}$ \\
\hline
\end{tabular}

The sample of investigations is made up as follows in Table 2.

Table 2: Sampling of investigations (cf. Görl-Rottstädt, 2011, p. 17)

\begin{tabular}{|l|l|}
\hline Methods & Number of persons surveyed \\
\hline Oral interviews & 42 \\
\hline Job observation & 51 \\
\hline Work shadowing & 18 \\
\hline Individual conversations, group discussions & 8 \\
\hline Quality Circle 1 & 5 \\
\hline Quality Circle 2 & 9 \\
\hline Evaluation of results and processes & 14 \\
\hline
\end{tabular}

In order to avoid possible conclusions about persons for data protection reasons, no reference to the assignment of the hierarchy is made here. While the results for the determination of the work structures were based on oral interviews and workplace observations, the work tasks could be analysed in group discussions. A number of different instruments were developed and used in this process. The evaluation of the interviews, workplace observations etc. is carried out using the method of qualitative content analysis based on Mayring (2015) and Gläser/Laudel (2006, p. 197). A comparative analysis based on a theoretical and practical frame of reference developed by the author helped to analyse the work tasks of prison officers. This allowed the collected data to be carefully evaluated.

In general, the flashback showed that the implementation of the studies did indeed create methodological problems. To quote Hohmeier (1973, p. 20), "it is difficult to define the role of a scientist, to allow critical distance and objectivity. The sensitization of the interviewees is a permanent process, because in their 'occupation-specific socialization' they have [learned] to build up a façade of external representation of their role to 'strangers'. From the author's point of view, this insight is confirmed and sensitized to win over the employees for the topic of the study and to create an open interview situation. 


\section{Selected results}

\section{Dealing with Changes in the Prison System - Starting Points for Adult Educational Findings}

It was important for the author to develop her own understanding of two concepts of learning counselling and learning support on which the research is based (see figure 2). The concepts of learning counselling and learning support are very closely related and overlap in their perception. Counselling also always implies support. The evolving concept of the learning organization emphasises a permanent work on process optimisation. In this context, Görl-Rottstädt (2011) sees the concept of learning support as a permanently anchored process integrated here.

\section{Social learning in and from institutions \\ - Reference to the term organizational development (cf. Schäfter, 1982)}

Change of an organization as a separate and completed event directly controlled by experts (cf. Benne/LangeLehngut, 2001)

\section{Conception of the learning organisation \\ - Paradigm for a shift to change and innovation (cf. Dünkel, 2002)}

Indirect management of change" as a "general, areawide competence of the organization (cf. Tremper, 2000)

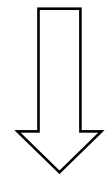

Learning counselling understood as a punctual and temporary stage in the development process

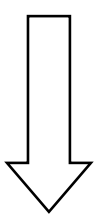

Learning support understood as a permanently integrated process

The terms learning counselling and learning support are understood as activities "helping learners to identify their learning needs, derive learning objectives, identify learning resources, develop a strategy, implement it and evaluate their own learning success". (Based on Pätzold, 2004, p. 7).

Figure 2: Perception of change in prison to explain the concepts of learning counselling an learning support (own representation according to Görl-Rottstädt, 2011, p. 47-49)

The understanding of learning counselling and learning support includes the relationship between the personnel responsible for further education, the learning locations in the context of developments and organizational. Figure 3 show that with regard to the connection between staff and learning location, the extern training centre, which is close to the justice system, has a focus on training outside the institution. However, they are also supported by prison managers, especially lawyers, specialists and social services. The situation of in-house training recruits $80 \%$ of its lecturers from its own staff (managers and specially trained employees of the general executive service). It is essential that external and internal further training is very closely interlinked. This can only be seen in the pool of lecturers, but also in the fact that there is a permanent exchange of information on current organizational and personnel developments and that needs are translated into adequate further training offers. The personnel presented here see themselves in their function as lecturers as learning advisors and learning supporters, starting in the external institution and continuing in the internal training as well as in the cooperation in the department. 


\section{Personnel with responsibility for further training in prisons}

Staff with authority and training management tasks

- $\quad$ Saxon State Ministry of Justice and for Democracy, Europe and Equality (SMJus)

- Head of Prison,

- $\quad$ full-time lecturers of the justice-related training centre

$\underline{\text { Staff with lecturing duties }}$

- full-time personnel of the justice-related training centre

- $\quad$ part-time staff from prisons, especially management staff

- $\quad$ freelance or self-employed personnel in the justice-related training centre

$\underline{\text { Staff with authority to issue instructions }}$

- Head of Prison

Personnel with educational management tasks

- $\quad$ Training and personnel managers in prisons

Staff with lecturing duties

- $\quad$ Training and personnel managers in prisons

- Managers (heads of institutions, departmental managers, departmental service managers, professional and social services)

- Multipliers, practical instructors, group leaders

- other members of the General Enforcement Service

- full-time personnel of the justice-related training centre
Learning

locations
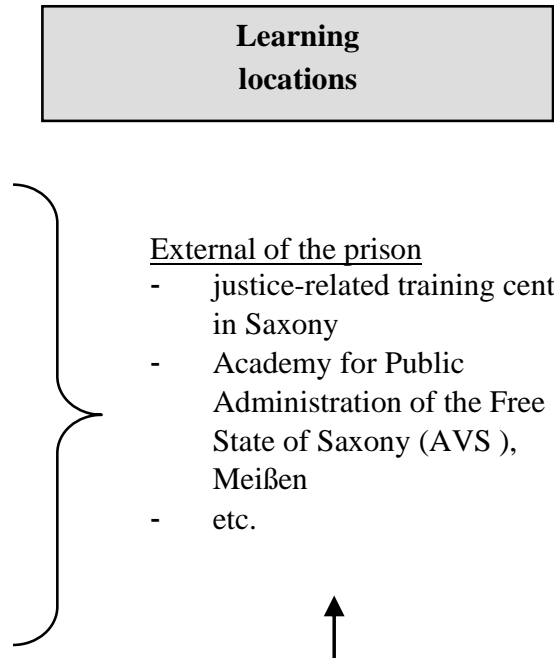

External of the prison justice-related training centre in Saxony

- $\quad$ Academy for Public Administration of the Free State of Saxony (AVS ), Meißen

- etc.

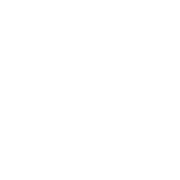

Internal of the

prison:

- organised internal training

- continuous training in the job and workplace independent further training

etc.

Figure 3: Closed relationship between personnel with responsibility for further training in prisons and learning locations (according to Rottstädt, 2006, p. 50 and further developed in Görl-Rottstädt, 2011, p.72; GörlRottstädt, 2019, p. 170)

Görl-Rottstädt moved to four levels of context when it comes to the contexts of learning counselling and support (ct. Görl-Rottstädt, 2011, p. 86):

- Personnel-oriented development processes, e.g. transformation, team development

- Prisoner oriented development processes, e.g. implementation of imprisonment according to separation principles and institutional profiles (first offender execution, residential group enforcement)

- Work structures, e.g. conference system, rotation, secondment, work shadowing, induction training

- Work tasks of the prison officers, e.g. carry out an inspection of the holding cell.

In further descriptions the focus is specialized on the level of work structures and work tasks. 


\section{Learning Potentials of Work Structures}

Work structures in author's opinion are structures which it can be understand as organized social forms that combine work and learning in work process. In the secondary analysis of the literature, two types of work structures were extracted: those with a singular event character and those with a character anchored in the daily routine. In the qualitative evaluation of the author's findings GörlRottstädt first discovered a differentiated structure: Namely, job changes, individual conversations and communication within the prisons. They can very well be assigned to these two types, so that I have also followed the references to the types found in my further comments in order to generate more stringent possibilities of comparison. In the description she has made it generally clear that the ideas of work-based learning have an effect on the perception of the work structures (ct. GörlRottstädt, 2011, p. 56-69 and p. 118-139, Görl-Rottstädt, 2019, p. 172). It will be illustrated by the following two examples.

The working structure of the rotation as an example of a singular event is positive, for short-term rotations with the right to return to the workplace. Here, in communicative processes, the view for the work processes of other departments is gained, experiences are exchanged. The understanding for each other is promoted. It becomes problematic when different interpretations of how to deal with prisoners collide. This leads to conflicts and to a high pressure to justify oneself. A permanent rotation of management staff can also lead to a reduction in room for maneuvers, as Görl-Rottstädt (2011, 2019) has learnt from conversations with staff members of the housing group prison, for example. The reduction of room for maneuvers affects job satisfaction: If a prison officer knows what else he or she could implement and he or she is cut back, motivation also decreases. The conflict situation with other staff about treatment approaches becomes all the more manifest, too. While on the one hand self-organised learning counselling and learning support takes place, on the other hand this is missing when dealing with conflicts as well as when securing standards of treatment. Possible solutions for the necessary learning guidance and support would be an open communicative handling of identified conflicts and the introduction of a knowledge management system (ct. Görl-Rottstädt, 2011, p. 123125, Görl-Rottstädt, 2019, p. 173).

As a second example of the work structure integrated during the day, Görl-Rottstädt $(2011,2019)$ chooses the conference system. Managers, such as specialist and social services, see here, particularly in terms of teamwork, in their role as learning advisors and companions. The integration of staff is new for everyone involved and must grow. Elements of reflection, irritation and feedback and also the handling of conflicts characterise the structure. Job satisfaction grows through recognised integration: the conference system is a kind of free space for learning for staff. And this can be transferred to the interaction with the prisoners in the cooperation, especially for example in the design of ward conferences where the prisoners are the centre of attention. Here, staff members experience the prisoner in group contexts, outside the normal station routine. These impressions shape the further working relationship between the staff in the team and the prisoners (as role model). The negative side is whether the conference system also receives this pedagogical character from the managers and can be developed by the team. If it is only used to pass on information, potential opportunities are lost (ct. Görl-Rottstädt, 2011, p. 134-138; Görl-Rottstädt, 2019, p. 173). 


\section{Learning potentials of work tasks}

If the work structures already contain these diverse learning potentials, but also lines of conflict, then it becomes all the more exciting as if the design of the work tasks is dedicated to the prison staff. In dealing with training documents of the judicial training centre and the business distribution plan, the author first of all worked out the basics in the creation of a systematic of work tasks of the prison officers. In order to describe the work tasks and their learnability and their learning content, GörlRottstädt (2011) has based the theory of the complete action of Hackers (1973) and indicators from KIBNET on a learning process guide. To assess the areas of competence Görl-Rottstädt $(2011,2020 \mathrm{~b})$ referred to the work of Erpenbeck and Heyse (1999) and Trier et al. (2001, p. 96) and used corresponding well-founded anchor examples as indicators. The practical and theoretical reference framework developed by the author is shown in Figure 4.

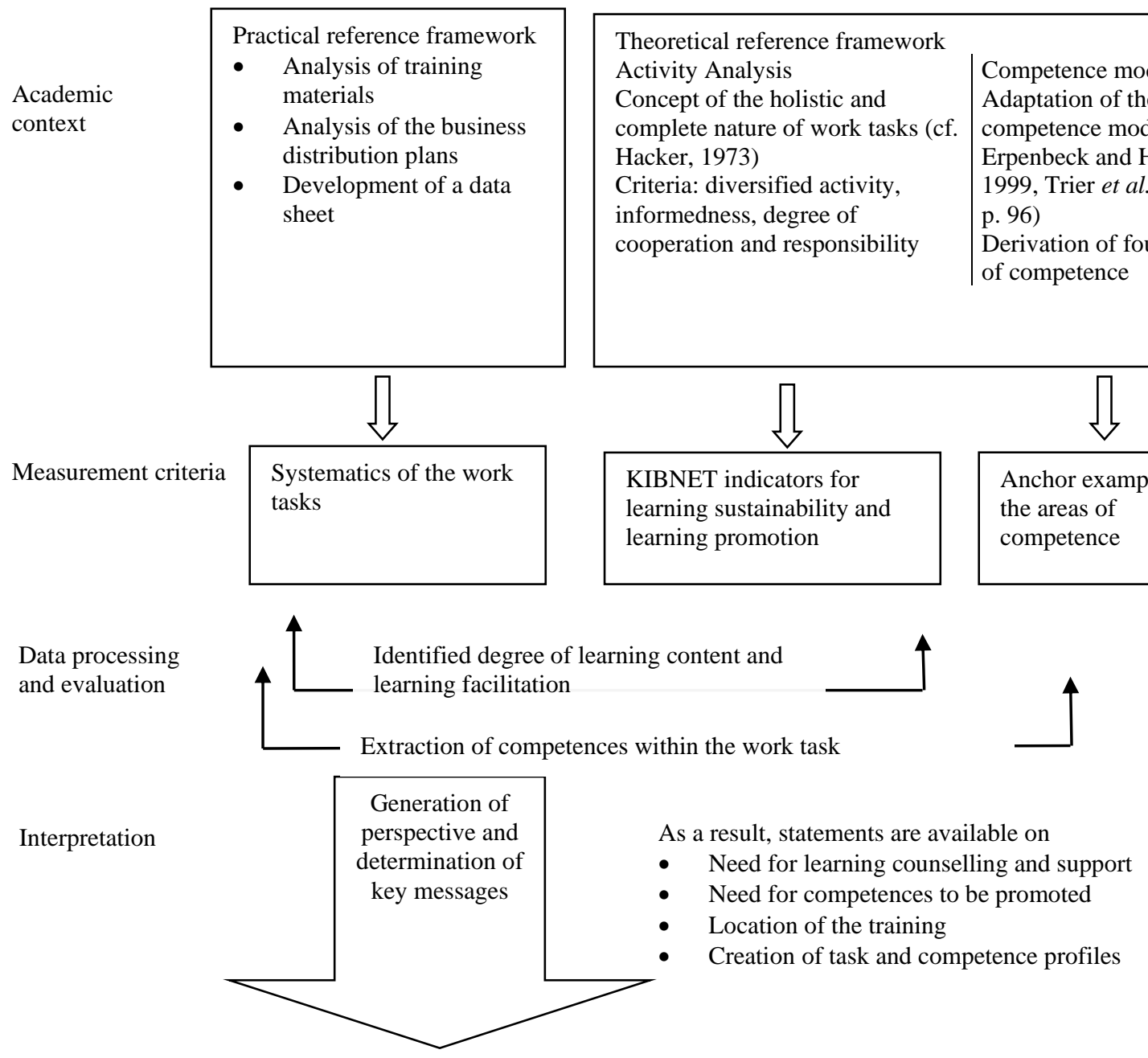

Figure 4: Reference framework for identifying the learning potential of prison officers' work tasks (in according to Görl-Rottstädt, 2011, p. 141)

As a result of the document analysis, the author determined a system of work tasks (cf. Görl-Rottstädt, 2011, p. 145), which were selected in the context of group discussions with the staff from Prison 1 and Prison 2 on the basis of 16 work task profiles for the further presentation of learning content and 
learning promotion and which were processed to the required extent with the interviewees (cf. GörlRottstädt, 2011, Annex 5:138-188). In the author's view, three typical forms of work tasks result in the assessment of development potential (see Table 3).

Table 3: Types of work tasks depending on the degree of learning content and learning facilitation (cf. GörlRottstädt, 2011, p. 149)

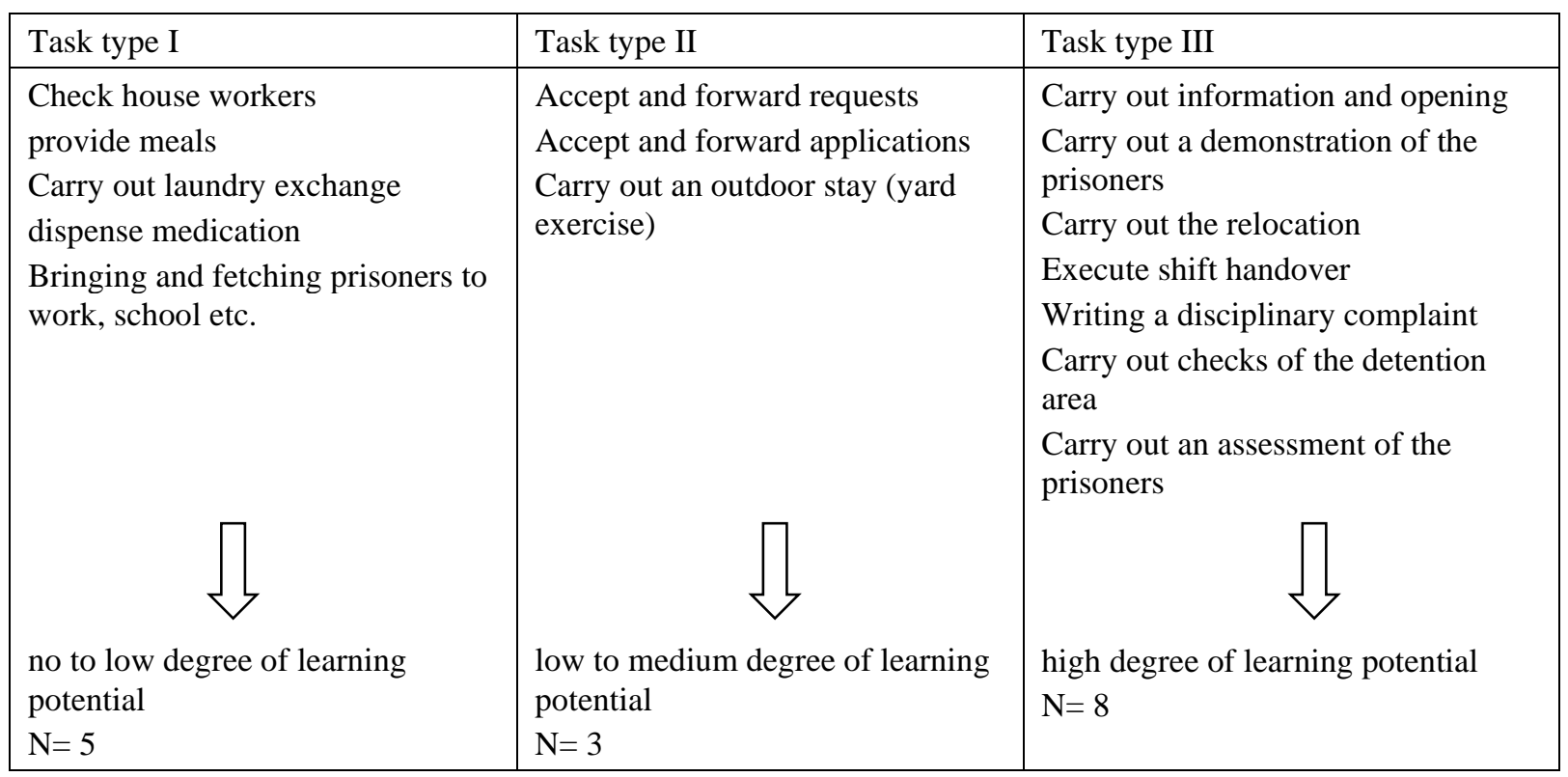

While task type I is evaluated in a very formalised way during the execution of the task, the social interaction of the staff with the prisoners of task types II to III increases, which also leads to a greater scope of action during the execution (cf. ibid, p.149-153). In the performance of the work tasks, the working and learning processes are very closely linked, in particular through the exchange of experience among the staff. Due to the formalisation of the work task, however, the scope for action is also very limited and, above all, has virtually no error tolerance. However, not only the processing of information is important, but also the access to all information in order to gain freedom of action. It is also a contradiction in terms to be restricted in the execution of the work task and at the same time to see the broader learning potential in relation to the design of the work structures or in the team processes. This is still a balancing act in which the employees have to work on what needs to be communicated. And is then also evident in the interaction with the prisoners (cf. Görl-Rottstädt, 2011, p.149-153).

As part of the description of the tasks, the staff and the author has used communicative validation to assess and weight the skills needed to carry out their work task (cf. Görl-Rottstädt, 2011, p. 156) and the she was able to generalize some following results:

1. New was the realization for the interviewees that all areas of competence in the execution of a work task belong to one; even if in different weighting. Not only are the technical and methodical competences in demand, but also the social competences, which in particular shape the social interaction with the prisoners. It can be communicated: Not only the participation in treatment and leisure groups is part of the treatment, but also the everyday life in the ward is treatment: I communicate an image 
that offers development opportunities in the perception of others and oneself and serves to improve the working climate as well as the motivation in the working context.

2. The description also has an effect on the design of internal further training. The author can illustrate the necessity of the competences to be promoted. Here above all the social competences. Thus, internal further training receives an incentive and must consider how it wants to methodically implement and promote the development of social competence. This underlines the authors plan for an increasingly competence-oriented design of further training.

3. (cf. Görl-Rottstädt, 2011, 158-171; Görl-Rottstädt, 2020b)

\section{Approach for the optimization of educational structures}

As the author had already described and experienced with the staff regarding the rotation of managers, she became more and more aware of the importance of securing achieved standards of individual and collective knowledge and competence of a learning organization. Görl-Rottstädt $(2011,2019)$ propose the need a solution for systematic learning guidance and support at the interfaces of internal departmental, internal, independent and external training. Her idea is to install a knowledge management system that is independent of individuals via the structure of the quality circle. In the synopsis of the four editors, the importance of learning guidance and support is given a constant dimension. There are already many good approaches, but also friction losses between the interfaces. Independent further training is still a blind spot (cf. Görl-Rottstädt, 2011, p. 185; Görl-Rottstädt, 2019, p. 177-179). This is shown in the next figure 5.

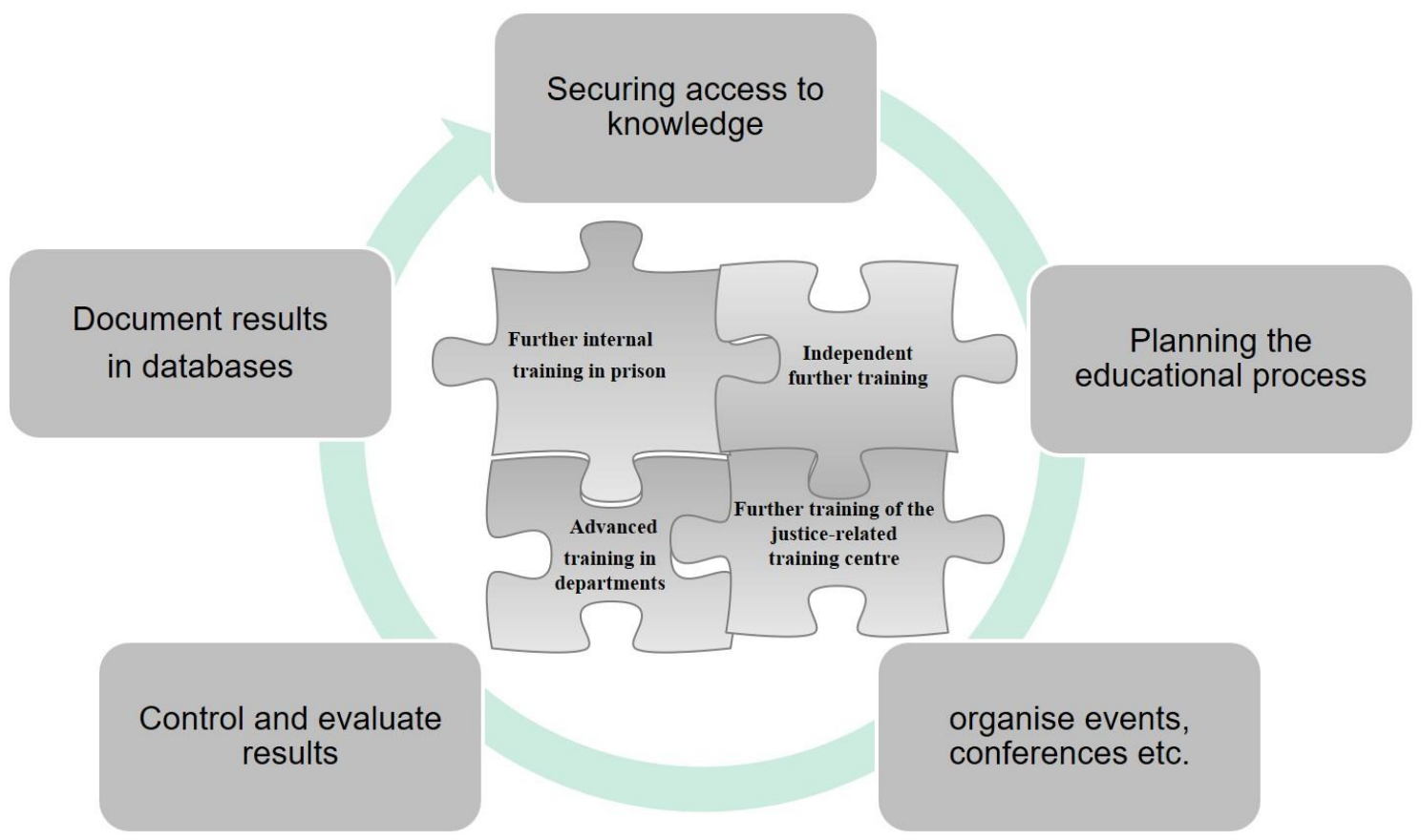

Figure 5: Introduction of a knowledge management system under the direction of the quality circle "inhouse training in prison" (in according to Görl-Rottstädt, 2011, p. 185)

\section{Conclusion}

In summary, Görl-Rottstädt $(2011,2019)$ can say that she has achieved the target she set herself. The present studies have shown directions of development and created a basis for the correctional 
facilities. The author has initiated sensitisation processes, and in addition Görl-Rottstädt $(2011,2018)$ has also been able to provide very practical recommendations for actions. It would be desirable if the learning potential of development processes, work structures and work tasks, as well as the discrepancies mentioned above, were to remain the subject of discussion. The same applies to the further development of the task and competence profiles of prison officers and other professional groups in the team, right up to the competence-oriented design of in-service training courses. The further research would expand to other occupational groups like social services. The transfer of results outside of prisons to other nonprofits, while desirable, appears to be limited.

It is essential to accept that only networked work and further training structures in a knowledge management system make it possible to design current and future processes of personnel and organizational development in order to develop prisons at a high level into a learning organization and to improve the image of the prison officers.

Initial approaches to solutions are being found to introduce the topic in higher education, e.g. the implementation of a resilience-promoting leadership behavior which gives implications for the transferability to socio-educational activities (Görl-Rottstädt and Knospe, 2021).

\section{References}

Aulerich, G., Fischer, E. and Hinz, H. et al. (2004, September). Kompetenzorientierte Lerngestaltung. Ein Konzept zur Personalentwicklung und Professionalisierung in Weiterbildungseinrichtungen. In QUEM, Berlin, Retrieved from https://www.kobra-berlin.de/wp-content/uploads/2018/01/Konzept2004.pdf [18/07/2021].

Benne, E. and Lange-Lehngut, K. (2001). Organisationsentwicklung zur Verbesserung der Aufbauund Ablauforganisation, In: Chr. Flügge, B. Maelicke and H. Preusker (Eds.). Das Gefängnis als lernende Organisation. Baden-Baden: Nomos, 117-135.

Berg, A., Heidrich, S. and Wolf, S. (2003). Tätigkeitsanalyse "Justizvollzugsbeamter im mittleren Dienst", Praktikumsbericht Arbeits- und Organisationspsychologisches Praktikum.

Bergmann, B. (2001, June). Handlungskompetenz und Arbeitsgestaltung. Höhere Anforderungen an ein Lernen im Prozess der Arbeit durch Veränderungen in der Arbeitswelt. In QUEM Bulletin 3/2001, 1-6, Retrieved from http://www.abwf.de/content/main/publik/bulletin/2001/B-3-01.pdf [18/07/2021].

Burgheim, J. and Ostheimer, W. (1994). Gesprächsführung in Konflikt- und Krisensituationen. Ein Curriculum zur Verbesserung der sozialen Kompetenzen der Beamten des allgemeinen Vollzugsdienstes in den baden-württembergischen Justizvollzugsanstalten. In StrVo 4/94, 207-215.

Dünkel, Frieder (2002, November, 27-29). Der deutsche Strafvollzug im internationalen Vergleich, Vortrag anlässlich der Tagung „Das Gefängnis als lernende Organisation“, Baden-Baden, 27.-29. November 2002. Retrieved from https://www.yumpu.com/de/document/read/38595231/der-deutschestrafvollzug-im-internationalen-vergleich-universitat-[18/07/2021].

Erpenbeck, J. and Heyse, V. (1999). Die Kompetenzbiographie. Strategien der Kompetenzentwicklung durch selbstorganisiertes Lernen und multimediale Kommunikation. In QUEM. Vol. 10. Münster, New York, München, Berlin.

Erpenbeck, J., Reuther, U., Weiß, R. et al. (2003, May). Zwei Jahre „Lernkultur und Kompetenzentwicklung“. Inhalte - Ergebnisse - Perspektiven. In QUEM-report. Issue 79, Berlin, Retrieved from http://www.abwf.de/content/main/publik/report/2003/Report-79.pdf [18/07/2021].

Gläser, J. and Laudel, G. (2006). Experteninterviews und qualitative Inhaltsanalyse als Instrumente rekonstruierender Untersuchungen, $2^{\text {nd }}$ edition. VS Verlag für Sozialwissenschaften, Wiesbaden. 
Goffman, E. (1973). Asyle. Über die soziale Situation psychiatrischer Patienten und anderer Insassen, Frankfurt am Main: Suhrkamp Verlag.

Görl-Rottstädt, D. (2011, Oktober). Transformation von Arbeitsproblemen in Lernprobleme Kompetenzentwicklungsbegleitende Lernberatung und -begleitung in sächsischen Justizvollzugsanstalten. Dissertation. Dresden, Retrieved from https://tud.qucosa.de/api/qucosa\%3A26758/attachment/ATT-0 [18/07/2021].

Görl-Rottstädt, D. (2019). Lernpotenziale im Arbeitsprozess entdecken und nutzbar machen - eine Analyse von Arbeitsstrukturen und Arbeitsaufgaben am Beispiel sächsischer Justizvollzugsanstalten. In J. Groß (Ed.). Soziologie für den öffentlichen Dienst (II) - Konflikte und Gewalt in öffentlichen Organisationen (NSI-Schriftenreihe), Maximilian Verlag, Hamburg, pp. 153-184.

Görl-Rottstädt, D. (2020a). Herausforderungen für Führungskräfte in der Umsetzung von Personalund Organisationsentwicklung im Justizvollzug - Fortbildung als strategisches und verbindendes Element, IN: Groß, Johanna (Hrsg.): Soziologie für den öffentlichen Dienst (III) - Führung: Perspektiven, Trends und Herausforderungen in Theorie und Praxis (NSI-Schriftenreihe), Maximilian Verlag, Hamburg, pp. 170-183

Görl-Rottstädt, D. (2020b). Lernhaltigkeit und Lernförderlichkeit von Arbeitsaufgaben im Allgemeinen Vollzugsdienst- Impulse für Bildungsprozesse in Justizvollzugsanstalten, ABWFBulletin 1, Juli 2020 Berlin, p. 7-15. Retrieved from https://www.abwf.de/wpcontent/uploads/2020/08/ABWF-Bulletin 2020.pdf [18/07/2021].

Görl-Rottstädt, D. and Knospe, Y. (2021): Resilienzförderliches Führungsverhalten erkennen und trainieren - Analyse sozialpädagogischen Handelns im Arbeitsfeld Justizvollzugsanstalt am Beispiel eines ausgewählten Moduls im Studiengang Sozialpädagogik und -management an der Fachhochschule Dresden (Workshop), 9. Tag der Lehre der FH OÖ, „Resilienz und Resilienzfaktoren in der Hochschullehre Anpassungsleistungen der Hochschuldidaktik in volatilen Zeiten“. Digital Moodle course from 20th-27th April 2021, FH OÖ, Linz.

Hacker, W. (1973). Allgemeine Arbeits- und Ingenieurspsychologie. Berlin: Deutscher Verlag der Wissenschaften.

Hofmann, M., Hupke, M. and Müller, A. (2003). Tätigkeitsanalyse „Justizvollzugsbeamter im mittleren Dienst". Bericht im Rahmen des Arbeits- und Organisationspsychologischen Praktikums, WS 2002/2003.

Hohmeier, J. (1973). Aufsicht und Resozialisierung. Eine empirische Untersuchung der Einstellungen von Aufsichtsbeamten und Insassen im Strafvollzug, Beiträge zur Strafvollzugswissenschaft. Issue 12, Ferdinand Enke Verlag, Stuttgart.

KIBNET - Kompetenzzentrum IT-Bildungsnetzwerke. Lernprozessbegleiter (n. d.). Lernförderliche Arbeitsbedingungen Checklisten. Retrieved from http://www.kibnet.org/fix/lpb/content/11_rahmenbedingungen/Checkliste-Arbeitsbedingung.pdf [28/07/2005].

Mayring, Ph. (2015). Qualitative Inhaltsanalyse. Grundlagen und Techniken, 8th Edition Beltz Verlag, Weinheim und Basel.

Pätzold, H. (2004). Lernberatung und Erwachsenenbildung. In R. Arnold (Ed.) (2004). Grundlagen der Erwachsenenbildung, Vol. 41. Schneider Verlag Hohengehren GmbH.

Rottstädt, D. (2006). Qualitätsentwicklung im Rahmen von Bildungsplanungs- und Lernberatungsprozessen. In: G. Wiesner (Ed.). Qualität in Bildung und Beratung - Lösungsansätze für die Qualitätsentwicklung in Weiterbildungseinrichtungen. saxoprint $\mathrm{GmbH}$, Dresden, 48-55.

Sauer, J. (2000). Genese des Forschungs- und Entwicklungsprogramms „Lernkultur und Kompetenzentwicklung“. In QUEM-Bulletin, 5/2000, 4-8.

Schäffter, O. (1982). Strafvollzugsreform durch institutionsbezogene Fortbildung: Ziele u. Strategien. Beiträge zur Strafvollzugswissenschaft, vol. 24, C. F. Müller Juristischer Verlag, Heidelberg. 
Tremper, U. (2000, June). Grundzüge betrieblicher Bildungsarbeit in Lernenden Organisationen Integration von Qualifizierung und Bildung am Beispiel des Gruppenlernens. Retrieved from http://webdoc.sub.gwdg.de/ebook/diss/2003/tu-berlin/diss/2000/tremper_udo.pdf [18/07/2021].

Trier, M., Hartmann, Th. and Aulerich, G. et al. (2001, Oktober). Lernen im sozialen Umfeld. Entwicklung individueller Handlungskompetenz. Positionen und Ergebnisse praktischer Projektgestaltung. In QUEM-report, Issue 70, Berlin, Retrieved from https://www.econstor.eu/bitstream/10419/105498/1/807094323.pdf [18/07/2021].

Wiesner, G., Häßler, H., Schober, B. and Rottstädt, D. (2003). Ermittlung des längerfristigen Fortbildungsbedarfs in den sächsischen Justizvollzugsanstalten (unpublished final report). 